\title{
PENILAIAN RISIKO KARIES MELALUI PEMERIKSAAN ALIRAN DAN KEKENTALAN SALIVA PADA PENGGUNA KONTRASEPSI SUNTIK DI KELURAHAN BANJER KECAMATAN TIKALA
}

\author{
${ }^{1}$ I Made W. A. Senawa \\ ${ }^{2}$ Vonny N. S. wowor \\ ${ }^{2}$ Juliatri
}

\author{
${ }^{1}$ Kandidat Skripsi Program Studi Pendidikan Dokter Gigi Fakultas Kedokteran \\ ${ }^{2}$ Program Studi Pendidikan Dokter Gigi Fakultas Kedokteran \\ Universitas Sam Ratulangi Manado \\ Email: made.winarto@gmail.com
}

\begin{abstract}
Caries still become a problem in many countries include Indonesia. Basic Health Research in 2007 showed that caries experience of Indonesian population reach $72.1 \%$ and North Sulawesi stand at third rank with $82.8 \%$. Determination of caries activity of individual can be done with caries risk assessment. Salivary flow and viscosity are included in caries risk assessment. Low salivary flow and high viscosity can show the presence of caries process. Hormonal contraception by injection is used widely in Indonesia. In 2013 women who used contraceptive injection were $49.42 \%$ and in North Sulawesi were $41.30 \%$. Estrogen and progesterone in injectable contraception are suspected to have ability to increase saliva secretion. This was a descriptive study with a crosssectional design conducted at Banjer, Tikala. Samples were obtained by using purposive sampling. Saliva was collected in 5 minutes filled in a container. The results showed that majority (43.1\%) had normal salivary flow and $61.4 \%$ had watery salivary viscosity. Conclusion: In this study, most women using contraceptive injection had normal salivary flow and moderate risk of caries. Salivary viscosity was in watery category with low caries risk
\end{abstract}

Keywords: caries risk, salivary flow, salivary viscosity, injectable contraception users

\begin{abstract}
Abstrak: Penyakit karies masih menjadi masalah di berbagai negara termasuk di Indonesia. Hasil Riset kesehatan Dasar tahun 2007 menunjukkan pengalaman karies yang diderita penduduk Indonesia mencapai 72,1\% dan Sulawesi Utara menempati urutan ketiga dengan 82,8\%. Penentuan aktivitas karies pada individu dapat dilakukan melalui penilaian risiko karies. Pemeriksaan aliran dan kekentalan saliva dapat digunakan untuk menilai risiko karies. Kecepatan aliran saliva dan dan kekentalan saliva dapat menunjukkan risiko karies individu. Kontrasepsi suntik merupakan jenis kontrasepsi hormonal yang semakin banyak dipakai di Indonesia. Tahun 2013 wanita pengguna Kontrasepsi Suntik di Indonesia sebanyak 49,42\% dan di Sulawesi Utara sebanyak 41,30\%. Kandungan hormon esterogen dan progesteron dalam Kontrasepsi Suntik diduga dapat meningkatkan sekresi saliva. Penelitian ini bersifat deskriptif dengan rancangan cross-sectional fan dilakukan di Kelurahan Banjer Kecamatan Tikala. Pengambilan sampel dengan menggunakan metode purposive sampling. Saliva selama 5 menit ditampung ke dalam wadah. Hasil penelitian menunjukkan mayoritas (43,1\%) memiliki aliran saliva normal dan 61,4\% memiliki kekentalan saliva yang tergolong encer. Simpulan: Sebagian besar pengguna Kontrasepsi Suntik di Kelurahan Banjer mempunyai aliran saliva normal dan risiko karies tergolong sedang. Kekentalan saliva berada pada kategori encer dengan risiko karies rendah.
\end{abstract}

Kata kunci: risiko karies, aliran saliva, kekentalan saliva, pengguna kontrasepsi suntik

Karies gigi merupakan salah satu penyakit infeksi jaringan keras gigi yang paling sering dan umum terjadi di seluruh lapisan masyarakat dari berbagai kelompok 
ekonomi dan usia. Karies gigi didefinisikan sebagai suatu penyakit mikrobiologi pada jaringan keras gigi yang ditandai dengan terjadinya demineralisasi bagian anorganik dan penghancuran dari substansi organik yang dapat menyebabkan rasa nyeri. ${ }^{1}$

Di Indonesia, prevalensi karies masih tinggi. Hasil Riset Kesehatan Dasar tahun 2007 menunjukkan pengalaman karies yang diderita penduduk Indonesia mencapai $72,1 \%$. Hasil riset tersebut juga menyatakan Sulawesi Utara menempati urutan ketiga dengan $82,8 \%$ penduduk yang pernah menderita penyakit karies. ${ }^{2}$ Angka tersebut menggambarkan kurang terawatnya kondisi kesehatan gigi dan mulut di Indonesia khususnya di Sulawesi Utara.

Karies disebabkan oleh empat faktor utama yaitu faktor host yang meliputi gigi dan saliva, mikroorganisme, substrat serta waktu sebagai faktor tambahan. Selain itu ada beberapa faktor yang dianggap berpengaruh terhadap karies gigi, antara lain riwayat dental sebelumnya, jenis kelamin, diet atau pola makan, oral hygiene, sosial ekonomi dan lain-lain., Jenis kelamin merupakan salah satu faktor yang berpengaruh pada terjadinya karies menunjukkan bahwa wanita lebih rentan terkena karies dibanding pria. ${ }^{5}$ Selain karies, wanita juga rentan terhadap penyakit mulut lainnya seperti gingivitis. Kondisi ini dipicu antara lain oleh adanya peningkatan kadar hormon esterogen dan progesteron yang dapat dihubungkan dengan masa menstruasi, sehingga mengakibatkan jaringan periodontal rentan terhadap peradangan. ${ }^{6,7}$

Saat ini hormon esterogen dan progesteron dimanfaatkan untuk mencegah kehamilan dan diaplikasikan dalam bentuk kontrasepsi hormonal. Kontrasepsi hormonal merupakan upaya mengontrol kehamilan dengan menggunakan hormon. Salah satu metode kontrasepsi hormonal yang umum dilakukan yaitu suntikan. Di Indonesia kontrasepsi suntik semakin banyak dipakai karena kerjanya yang efektif, pemakaiannya yang praktis, harganya relatif murah dan aman.
Hasil survei Badan Kependudukan dan Keluarga Berencana Nasional (BKKBN), yaitu lembaga yang bertugas mengurus masalah kependudukan secara nasional, menunjukkan bahwa metode kontrasepsi hormonal merupakan kontrasepsi yang banyak diminati oleh akseptor. Hasil survei menggambarkan peserta keluarga berencana (KB) aktif wanita pengguna kontrasepsi hormonal berupa suntikan tahun 2013 menempati urutan pertama dengan persentase (49,42\%), diikuti pengguna pil dengan persentase $(24,76 \%)$ dan implan sebanyak (10,14\%). Masih dari data yang sama menggambarkan pengguna kontrasepsi hormonal di Sulawesi Utara dilihat dari peserta KB aktif wanita, menunjukkan bahwa penggunaan Kontrasepsi Suntik paling disukai dengan persentase $41,30 \%$ diikuti pil $26,43 \%$ dan implan 17,69\%. Dari data tersebut nampak bahwa kontrasepsi suntik ialah jenis kontrasepsi yang paling banyak dipilih oleh masyarakat peserta KB. ${ }^{8}$

Beberapa penelitian menunjukkan adanya peningkatan $\mathrm{pH}$ dan volume saliva pada pengguna kontrasepsi pil dan suntik. Hal ini dikaitkan dengan kandungan hormon esterogen dan progesteron pada kontrasepsi tersebut yang diduga berperan dalam meningkatkan sekresi saliva. ${ }^{6}$ Sekresi saliva yang meningkat akan meningkatkan konsentrasi komponen organik dan anorganik antara lain kalium, fosfat, HCO3, florida dan lain-lain, yang tidak memberikan kesempatan bagi bakteri mulut untuk berkembang biak sehingga menghambat terjadinya karies. ${ }^{9}$

Penentuan aktivitas karies pada individu dapat dilakukan melalui penilaian risiko karies. Salah satu tujuan dilakukan penilaian risiko karies ialah untuk membantu mengidentifikasi faktor yang berperan pada karies tersebut sehingga membantu memprediksi kerentanan seseorang terhadap karies saat ini atau karies yang akan datang. Salah satu pemeriksaan dalam penilaian risiko karies yaitu pemeriksaan aliran dan kekentalan saliva. Kecepatan aliran saliva yang rendah dan kekentalan saliva yang tinggi dapat 
menunjukkan tingginya proses terjadinya karies. Sebaliknya kecepatan aliran yang tinggi dan kekentalan saliva yang rendah menunjukkan rendahnya kejadian karies. ${ }^{10}$ Berdasarkan beberapa alasan tersebut di atas, penulis tertarik untuk melakukan penelitian tentang penilaian risiko karies pada pengguna $\mathrm{KB}$ suntik melalui pemeriksaan aliran dan kekentalan saliva.

\section{METODE PENELITIAN}

Penelitian ini merupakan penelitian deskriptif dengan pendekatan cross sectional di kelurahan Banjer kecamatan Tikala kota Manado. Populasi penelitian yaitu peserta KB aktif berumur 18-49 tahun yang berjumlah 174 orang.

Kriteria inklusi ialah Pengguna Kontrasepsi Suntik dan Bersedia terlibat dalam penelitian sebagai responden. Kriteria eksklusi ialah sedang menggunakan alat ortodonsia lepasan atau alat ortodonsia cekat, sedang menggunakan gigi tiruan, sedang mengalami infeksi saluran pernapasan, sedang menjalani kemoterapi, atau tidak bersedia terlibat dalam penelitian.

Besar sampel dihitung berdasarkan prevalensi pengguna Kontrasepsi Suntik di Sulawesi Utara (41,30\%) dari populasi sebanyak 174 dan didapatkan sampel sebanyak 72 orang. Pengambilan sampel dilakukan dengan metode purposive sampling.

Penilaian risiko karies ialah cara yang digunakan peneliti untuk memrediksi kemungkinan aktivitas karies pengguna kontrasepsi suntik di Kelurahan Banjer Kecamatan Tikala Baru melalui pemeriksaan aliran dan kekentalan saliva. Penilaian risiko karies berdasarkan pemeriksaan aliran saliva:

a. Risiko karies rendah, bila aliran saliva lambat

b. Risiko karies sedang, bila aliran saliva normal

c. Risiko karies tinggi, bila aliran saliva cepat

Penilaian risiko karies berdasarkan pemeriksaan kekentalan saliva: a. Risiko karies rendah, bila saliva encer

b. Risiko karies sedang, bila aliran saliva normal

c. Risiko karies tinggi, bila aliran saliva kental

Aliran saliva ialah sekresi saliva pengguna Kontrasepsi Suntik yang diukur dengan dengan menampung saliva ke dalam gelas ukur selama 5 menit. Aliran saliva rata-rata dihitung berdasarkan jumlah saliva yang terkumpul dibagi waktu yang digunakan untuk mengumpul saliva. Kriteria aliran saliva :

a. Aliran lambat, bila alirannya $<0,7$ $\mathrm{mL} / \mathrm{menit}$.

b. Aliran normal, bila alirannya di antara 0,7-1 mL/menit.

c. Aliran cepat, bila alirannya $>1$ $\mathrm{mL} / \mathrm{menit}$.

Kekentalan saliva merupakan kondisi saliva pengguna Kontrasepsi Suntik yang berhubungan erat dengan hambatan untuk mengalir.

Kriteria kekentalan saliva:

a. Encer, apabila saliva terlihat bening, cair, tidak berbusa, dan bila gelas dimiringkan, saliva langsung mengalir cepat seperti air.

b. Normal, apabila saliva terlihat putih, berbusa, dan bila gelas dimiringkan, saliva mengalir perlahan.

c. Kental : Lengket, putih, berbusa, bila gelas dimiringkan hampir tidak mengalir.

Pengguna Kontrasepsi Suntik ialah masyarakat Kelurahan Banjer Kecamatan Tikala peserta KB aktif yang menggunakan Kontrasepsi Suntik untuk mencegah terjadinya kehamilan.

Data primer diperoleh secara langsung dari responden melalui wawancara dan pemeriksaan menggunakan formulir pemeriksaan dan checklist pada masyarakat Kelurahan Banjer Kecamatan Tikala Kota Manado. Sebelum penelitian dilakukan, diinformasikan bahwa selama penelitian berlangsung subjek tidak diperbolehkan untuk makan dan minum selama 30 menit. Subjek penelitian diinstruksikan untuk duduk sambil menundukkan kepala kurang 
lebih $45^{\circ}$ terhadap lantai. Mulut agak dibuka kemudian saliva dibiarkan mengalir ke dalam wadah saliva. Apabila saliva sukar keluar dapat dibantu dengan lidah mendorong saliva masuk ke dalam wadah saliva. Pengumpulan saliva dilakukan selama 5 menit dengan cara saliva ditampung ke dalam wadah saliva dan dihitung kecepatan alirannya. Saliva yang terkumpul dalam wadah kemudian diukur kekentalannya dengan pemeriksaan visual untuk dinilai kekentalannya. Berdasarkan hasil pemeriksaan aliran dan kekentalan saliva kemudian ditentukan risiko karies pada masing-masing pemeriksaan. Data yang telah dikumpulkan kemudian diolah dengan bantuan komputer, disajikan dalam bentuk tabel distribusi frekuensi dan dianalisis.

\section{HASIL PENELITIAN}

Kelurahan Banjer merupakan salah satu kelurahan yang berada di Kecamatan Tikala Kota Manado dan merupakan salah satu wilayah kerja Puskesmas Tikala Baru. Data puskesmas menunjukkan jumlah wanita usia subur (WUS) di kelurahan Banjer sebanyak 2799 orang. Berdasarkan data terakhir yang diperoleh terdapat 174 wanita peserta KB aktif di kelurahan Banjer kecamatan Tikala.

Berdasarkan data pada Tabel 1, wanita berusia 26-35 tahun merupakan pengguna Kontrasepsi Suntik terbanyak yakni 37 orang (51,4\%) diikuti berturut-turut kelompok usia 36-45 tahun sebanyak 18 orang (25\%), kelompok usisa 18-25 tahun sebanyak 15 orang (20,8\%) dan kelompok usia 46-50 tahun sebanyak 2 orang (2,8\%).

Tabel 1. Distribusi responden berdasarkan usia

\begin{tabular}{lcc}
\hline $\begin{array}{l}\text { Usia } \\
\text { (tahun) }\end{array}$ & $\begin{array}{c}\text { Jumlah } \\
\text { responden (n) }\end{array}$ & $\mathbf{\%}$ \\
\hline $18-25$ & 15 & 20,8 \\
$26-35$ & 37 & 51,4 \\
$36-45$ & 18 & 25 \\
$46-50$ & 2 & 2,8 \\
\hline Total & 72 & 100,0 \\
\hline
\end{tabular}

Lamanya penggunaan Kontrasepsi Suntik oleh responden didistribusikan hasilnya dalam Tabel 2.

Tabel 2. Distribusi responden berdasarkan lamanya penggunaan kontrasepsi suntik

\begin{tabular}{ccc}
\hline $\begin{array}{c}\text { Lama } \\
\text { penggunaan }\end{array}$ & $\begin{array}{c}\text { Jumlah } \\
\text { responden (n) }\end{array}$ & $\mathbf{\%}$ \\
\hline$<1$ tahun & 7 & 9,72 \\
$1-5$ tahun & 54 & 75 \\
$6-10$ tahun & 8 & 11,11 \\
$11-15$ tahun & 3 & 4,17 \\
\hline Total & 72 & 100 \\
\hline
\end{tabular}

Data pada Tabel 3 menunjukkan bahwa sebanyak 31 responden (43\%) memiliki aliran saliva $0,7-1 \mathrm{ml} / \mathrm{menit}$ (normal); 22 responden (30,6\%) memiliki aliran saliva $<0,7 \mathrm{ml} /$ menit (lambat); 19 responden $(26,4 \%)$ memiliki aliran saliva $>1 \mathrm{ml} / \mathrm{menit}$ (cepat) dan rerata aliran saliva $0,93 \mathrm{ml} / \mathrm{menit}$ (normal).

Tabel 3. Distribusi pemeriksaan aliran saliva responden

\begin{tabular}{cccc}
\hline $\begin{array}{c}\text { Aliran } \\
\text { Saliva } \\
\text { (ml/menit) }\end{array}$ & $\begin{array}{c}\text { Jumlah } \\
\text { (n) }\end{array}$ & \% & Kategori \\
\hline$<0,7$ & 22 & 30,6 & Lambat \\
$0,7-1$ & 31 & 43 & Normal \\
$>1$ & 19 & 26,4 & Cepat \\
\hline Rerata & Total & 100 & Rerata: \\
aliran: 0,93 & 72 & & Normal \\
\hline
\end{tabular}

Data hasil penilaian risiko karies pada Tabel 4 memperlihatkan bahwa sebanyak 31 responden (43\%) memiliki aliran saliva yang dikategorikan normal dengan risiko karies sedang, 22 responden (30,6\%) memiliki aliran saliva lambat dengan risiko karies tinggi dan sebanyak 19 responden (26,4\%) memiliki aliran saliva cepat dengan risiko karies rendah. Secara keseluruhan rerata aliran saliva responden tergolong normal dengan rerata risiko karies sedang. 
Tabel 4. Distribusi status gingiva berdasarkan jenis kelamin

\begin{tabular}{|c|c|c|c|}
\hline Aliran & $\begin{array}{c}\text { Jumlah } \\
\text { (n) }\end{array}$ & $\%$ & Risiko karies \\
\hline Lambat & 22 & 30,6 & Tinggi \\
\hline Normal & 31 & 43 & Sedang \\
\hline Cepat & 19 & 26,4 & Rendah \\
\hline $\begin{array}{l}\text { Rerata } \\
\text { Normal }\end{array}$ & 72 & 100 & Rerata Sedang \\
\hline
\end{tabular}

Data pada Tabel 5 menunjukkan sebanyak 37 responden (51,4\%) memiliki saliva encer, 21 responden (29,2\%) memiliki saliva normal dan sebanyak 14 responden $(19,4 \%)$ memiliki saliva kental. Data pada Tabel 6 menunjukkan sebanyak
37 responden $(61,4 \%)$ memiliki saliva encer dengan risiko karies rendah, 21 responden $(29,2 \%)$ memiliki saliva normal dengan risiko karies sedang dan 14 responden lainnya $(19,4 \%)$ memiliki saliva kental dengan risiko karies tinggi.

Tabel 5. Distribusi pemeriksaan kekentalan saliva responden

\begin{tabular}{|c|c|c|c|}
\hline Kekentalan Saliva & Jumlah (n) & $\%$ & Kategori \\
\hline Bening, cair, tidak berbusa, mengalir cepat & 37 & 51,4 & Encer \\
\hline Putih, berbusa, mengalir pelan & 21 & 29,2 & Normal \\
\hline Putih, berbusa, lengket, hampir tidak mengalir & 14 & 19,4 & Kental \\
\hline & Total 72 & 100 & \\
\hline
\end{tabular}

Tabel 6. Distribusi penilaian risiko karies responden berdasarkan pemeriksaan kekentalan saliva

\begin{tabular}{cccc}
\hline Kekentalan & $\begin{array}{c}\text { Jumlah } \\
\text { (n) }\end{array}$ & \% & $\begin{array}{c}\text { Risiko } \\
\text { karies }\end{array}$ \\
\hline Encer & 37 & 51,4 & Rendah \\
Normal & 21 & 29,2 & Sedang \\
Kental & 14 & 19,4 & Tinggi \\
\hline & Total 72 & 100 &
\end{tabular}

\section{BAHASAN}

Penelitian yang dilakukan di Kelurahan Banjer Kecamatan Tikala memberikan gambaran karakteristik usia yang beragam. Dari hasil penelitian yang telah dilakukan seperti yang digambarkan pada Tabel 3 menunjukkan, bahwa responden dengan golongan usia 26-35 tahun merupakan yang paling banyak menggunakan Kontrasepsi Suntik. Pada golongan usia tersebut umumnya memiliki kecenderungan rasa ingin tahu yang tinggi, sehingga responden banyak mengakses informasi yang dipublikasikan melalui media elektronik maupun media cetak. Hal ini dapat meningkatkan pengetahuan responden secara umum, dan mungkin termasuk pengetahuan di bidang kesehatan dan pemanfaatan kontrasepsi untuk mencegah kehamilan. Banyaknya pengetahuan yang dimiliki akan mendorong responden untuk memilih penggunaan Kontrasepsi Suntik dalam mencegah kehamilan.

Hasil pemeriksaan aliran saliva untuk menilai risiko karies sebagaimana termuat dalam Tabel 5 dan Tabel 6, menunjukkan bahwa sebagian besar responden yakni sebanyak 43,1\% memiliki aliran saliva normal. Secara teori, penggunaan kontrasepsi yang mengandung hormon esterogen dan progesteron dapat meningkatkan aliran saliva. Hal ini sejalan dengan penelitian Handajani dkk yang dilakukan di Sleman Yogyakarta tahun 2010 yang menyatakan penggunaan 
kontrasepsi hormonal di atas 3 bulan akan meningkatkan aliran saliva. Adanya penambahan esterogen dan progesteron dalam tubuh akan merangsang sekresi saliva. ${ }^{6}$ Esterogen dan progesteron yang terkandung dalam kontrasepsi suntik diduga berperan dalam peningkatan kortisol saliva. Kortisol berikatan dengan Glukokortikoid Reseptor (GR) yang didistribusikan secara luas dalam otak, termasuk prefrontal cortex dan dengan afinitas yang tinggi terhadap Mineralocorticoid Reseptor yang terdapat dalam jumlah banyak di limbic area. Kortisol juga dapat memengaruhi beberapa sistem neurotransmitter catecholaminergic seperti adrenergic, dopaminergic, serotonergik melalui mekanisme rapid nongenomik. Aktivitas sekresi pada glandula salivatorius diinervasi oleh kelenjar simpatis dan parasimpatis. Peningkatan kortisol akan memengaruhi aktivitas saraf simpatis melalui reseptor $\alpha$ dan $\beta$ adrenergik sehingga meningkatkan sekresi saliva. Sekresi saliva berkaitan dengan aliran saliva. Aliran saliva dihitung berdasarkan volume saliva yang mengalir permenit. Aliran saliva yang meningkat menyebabkan risiko karies rendah, sebaliknya aliran saliva yang lambat menyebabkan risiko karies tinggi.

Aliran saliva yang lambat dapat menurunkan kapasitas buffer saliva yang dapat menurunkan $\mathrm{pH}$ saliva sehingga menjadi salah satu faktor penyebab meningkatnya risiko perkembangan karies. Hal ini sejalan dengan penilitian Tecky Indriana yang dilakukan di Jember pada tahun 2011 menyebutkan aliran saliva yang rendah akan menurunkan konsentrasi bikarbonat sehingga kapasitas buffer menurun yang akan meningkatkan risiko karies. $^{11}$

Namun dalam penelitian yang telah dilakukan di kelurahan Banjer kecamatan Tikala, menunjukkan hasil yang berbeda yakni mayoritas responden memiliki aliran saliva yang dikategorikan normal. Hal ini mungkin disebabkan oleh karena responden menggunakan Kontrasepsi Suntik secara tidak teratur sebagaimana seharusnya, sehingga kondisi ini berpengaruh terhadap kadar hormon estrogen dan progesteron dalam tubuh responden. Kadar hormon dalam tubuh responden belum memberikan efek nyata pada peningkatan aliran saliva. Selain itu mungkin juga ada responden yang mengonsumsi obat-obatan yang dapat menyebabkan aliran saliva berkurang, sehingga efek bertambahnya aliran saliva akibat penggunaan Kontrasepsi Suntik tidak terlalu nyata terlihat.

Kekentalan saliva berperan dalam kemampuan saliva membersihkan sisa-sisa makanan dari dalam rongga mulut. Saliva yang encer akan memiliki efek self cleansing yang membantu saliva secara alami membersihkan sisa makanan sehingga tidak menempel dengan erat pada permukaan gigi. Sebaliknya saliva yang kental akan menyebabkan terjadinya retensi sisa makanan pada permukaan gigi, sehingga meningkatkan risiko karies. Pada penelitian ini hasil yang diperoleh sebelumnya menunjukkan bahwa aliran saliva normal. Hasil ini seharusnya sejalan dengan pemeriksaan kekentalan saliva, yakni hasilnya normal juga., sebagaimana hasil yang didapat dari penelitian Moch Rodian dkk yang dilakukan di Medan tahun 2010. ${ }^{12}$ Namun hasil yang diperoleh sebagaimana yang disajikan dalam Tabel 7 dan Tabel 8 menunjukkan bahwa sebagian besar responden (51,4\%) memiliki kekentalan saliva masuk dalam kategori encer. Saliva yang encer seharusnya memiliki aliran yang cepat, tetapi pada penelitian ini menunjukkan hasil alirannya normal. Apabila aliran salivanya normal, maka kekentalan saliva seharusnya juga normal sehingga penilaian risiko kariesnya memiliki hasil yang sama. Menurut pendapat penulis, hasil yang ada dipengaruhi oleh penilaian kekentalan saliva yang dilakukan hanya berdasarkan persepsi dari pemeriksaan visual terhadap kondisi saliva. Pemeriksaan yang dilakukan secara visual berdasarkan persepsi seseorang akan memberikan hasil yang kurang valid. Pada pemeriksaan ini, penulis dibantu oleh beberapa rekan, sehingga persepsi bisa memberikan hasil yang 
berbeda walaupun sebelumnya sudah dilakukan kalibrasi. Hal ini bisa terjadi karena tidak menggunakan alat ukur yang baku. Hasil penelitian mungkin memberikan hasil yang berbeda jika menggunakan alat ukur yang baku seperti Viscometer (alat untuk mengukur kekentalan). Penelitian ini memiliki keterbatasan karena penulis sulit memperoleh alat ukur yang baku untuk mengukur kekentalan, sehingga alat ukur yang digunakan berupa persepsi penulis terhadap kekentalan yang sudah dideskripsikan. Dengan demikian dari kedua pemeriksaan di atas, maka pada penelitian ini penulis cenderung lebih memercayai hasil penilaian risiko karies berdasarkan pemeriksaan aliran saliva, oleh karena pemeriksaan yang dilakukan menggunakan alat ukur yang baku yakni gelas ukur dan stopwatch.

Risiko karies pada masing-masing individu berbeda-beda dikarenakan setiap individu memiliki keadaan rongga mulut yang berbeda. Penilaian dalam risiko karies juga tidak hanya dapat dipastikan hanya melalui salah satu faktor penilaian melainkan dapat dikombinasikan dengan pemeriksaan yang lain sehingga dapat memprediksi risiko karies yang akan datang.

\section{SIMPULAN}

Berdasarkan hasil penelitian dapat disimpulkan bahwa pada pengguna kontrasepsi suntik di Kelurahan Banjer aliran saliva sebagian besar berada pada kategori normal, kekentalan saliva berada pada kategori yang encer, risiko karies pada pengguna kontrasepsi suntik yang aliran salivanya normal, berada pada kategori sedang, sedangkan risiko karies pada pengguna kontrasepsi suntik yang salivanya encer berada pada kategori rendah.

\section{SARAN}

1. Bagi pemerintah diharapkan dapat menggunakan instansi yang ada untuk meningkatkan program promotif dan preventif kesehatan gigi dan mulut serta mengoptimalkan program penggunaan kontrasepsi hormonal dalam mengontrol pertambahan penduduk.

2. Bagi masyarakat diharapkan dapat merasakan manfaat program pemerintah dan dapat mengaplikasikan ilmu yang telah didapat dalam program pemerintah sehingga derajat kesehatan gigi dan mulut akan lebih meningkat, demikian halnya dengan kesejahteraan masyarakat akibat pertambahan penduduk yang terkontrol.

3. Diharapkan adanya penelitian lebih lanjut mengenai penilaian risiko karies dengan cakupan yang lebih beragam, sehingga hasilnya dapat digunakan secara umum untuk pengembangan kesehatan gigi dan mulut.

\section{DAFTAR PUSTAKA}

1. Chandra S, Chandra G, Chandra S. Text book of operative dentistry. First edition. New delhi: Jaypee Brothers Medical Publishers (P) Ltd, 2007. p. 36

2. Riset Kesehatan Dasar. Laporan kesehatan gigi dan mulut; 2007. 140-2

3. Kidd EAM, Bechal SJ. Dasar-dasar karies penyakit dan penanggulangannya. Cetakan 2. Jakarta: EGC, 1991. Hal 1-96.

4. Rethman J.Trends in preventive care : caries risk assessment and indications for sealant.JADA. 2000;131:8-11.

5. Basavaraj P, Khuller $N$, Khuller R, Sharma N. Caries Risk Assessment and Control. Journal of oral health and comunity dentistry 2011;15(1):258-63.

6. Handajani J, Puspita RM, Amelia R. Contraceptive pill and injection increase $\mathrm{pH}$ and volume of saliva. Dentika Dental Journal 2010;15(1):15.

7. Amalia R. Gambaran status $\mathrm{pH}$ dan volume saliva pada pengguna kontrasepsi hormonal di Kecamatan Mappakasunggu Kabupaten Takalar. Universitas Hasandin. [online] 2013 [cited 2014 mar 7]; Availble from:URL:http://repository.unhas.ac.i d/handle/123456789/7825.

8. Hasil pelaksanaan subsitem pencataan dan pelaporan pelayanan kontrasepsi 
2014. Badan Kependudukan dan Keluarga Berencana Nasional Direktorat Pelaporan dan Statistik. 2014

9. Pardede R. Peranan saliva dalam melindungi gigi terhadap karies. Medan: Universitas Sumatera Utara. [online] 2004 [cited 2014 Feb 26]; Available from: URL:http://repository.usu.ac.id/bitstre am/123456789/8234/1/000600087.pd $\mathrm{f}$

10. Bahar A. Paradigma baru pencegahan karies gigi. Jakarta: Fakultas Ekonomi Universitas Indonesia, 2011: 59-65
11. Indriana T. Perbedaan laju aliran saliva dan $\mathrm{pH}$ karena pengaruh stimulus kimiawi dan mekanis. J. Kedokt Meditek 2011;17(44).

12. Rodian M, Satari M.H, Rolleta E. Efek mengunyah permen karet yang mengandung sukrosa xylitol, probiotik, terhadap volume, kecepatan aliran, viskositas, $\mathrm{pH}$, dan jumlah streptococcus mutans saliva. Bagian oral biologi fakultas kedokteran gigi universitas padjajaran. [online] [cited2014Okt30] :Availblefrom:URL:http://pustaka.un pad.ac.id/wpcontent/upload/2013/06/ efek_mengunyah_permen_karet2.pdf 